Doi: $10.15863 / \mathrm{TAS}$

\section{International Scientific Journal}

\section{Theoretical \& Applied Science}

p-ISSN: 2308-4944 (print) e-ISSN: 2409-0085 (online)

Year: $2015 \quad$ Issue: $01 \quad$ Volume: 21

Published: $30.01 .2015 \quad$ http://www.T-Science.org
Nurlan Muhtarovich Batyrbaev

Candidate of law science, professor,

The faculty of social Science, Law department International Kazakh-Turkish University by name of

H.A.Yessevi, Kazakhstan

Yernar Sailaubekovich Shalkharov

Postgraduate student in $\mathrm{PhD}$ programme

The faculty of social science, law department International Kazakh-Turkish University by name of H.A.Yessevi, Kazakhstan yernarshalkharov@,bk.ru

Shamuhamet Nurmuhamedovich Akmadov Postgraduate student in master programme

The faculty of social science, law department International Kazakh-Turkish University by name of H.A.Yessevi, Kazakhstan

\title{
PROBLEMS OF CONSUMER PROTECTION LEGISLATION IN THE SPHERE OF MEDICAL EDUCATION SYSTEM AS A COURSE TO ACHIEVE GOAL OF CORRECT CONNECTION BETWEEN DOCTOR AND PATIENT IN KAZAKHSTAN, CENTRAL ASIA, DISCRIPTING APPROACH
}

Abstract: In this article there were shown the main features of consumer legal relationship in the sphere of medical education, based on the main principles of developing education system from the point of consumer protection legislation. It is very necessary to improve the situation in medical conflicts during the present situation in Kazakhstan.

Key words: quantity, quality, consumer, good, services, legislation, legal norms, formation, medical transaction, civil, code.

Language: English

Citation: Batyrbaev NM, Shalkharov YS, Akmadov SN (2015) PROBLEMS OF CONSUMER PROTECTION LEGISLATION IN THE SPHERE OF MEDICAL EDUCATION SYSTEM AS A COURSE TO ACHIEVE GOAL OF CORRECT CONNECTION BETWEEN DOCTOR AND PATIENT IN KAZAKHSTAN, CENTRAL ASIA, DISCRIPTING APPROACH. ISJ Theoretical \& Applied Science 01 (21): 126-128. doi: http://dx.doi.org/10.15863/TAS.2015.01.21.21

\section{Introduction.}

Nowadays normative base, providing to the consumer basic rights corresponding to the international standards, operates in Republic of Kazakhstan are failed to complete of the system of the socially-legal providing of rights for consumers generates the great number of problems special concerning the sector of providing of medical services. Practice shows systematic abuses from the side of commercial sector as professional participants of the market relations based on absence of the legislatively envisaged mechanisms of defense of consumers in their consumer rights especially from medical workers.

Brief compare analyses.

Today the legal status of participants of consumer relations that in turn was transformed in the forms of protection of consumers changed for all period of forming and development of Republic of Kazakhstan, and responsibility of businessmen continued to become complicated. In this connection more deep understanding of all subtleties of the system of the socially-legal providing of protection of consumers is impossible without the analysis of her origin.

Deepening it is possible to suppose in sources, that Republic of Kazakhstan is the young, dynamically developing state, but on some opinions, operating of mechanism under the protection of consumers was put on the brakes by the system the USSR, in accordance with that control after all commercial sector and all the production came true by the state. Nevertheless even in the USSR a mechanism took place on the protection of consumers. 
The maiden attempt of Soviet Union consisted in creation of the special legislation that was worked out by an autumn 1988 as a project of Law of the USSR "About quality of products and protection of consumers". Basic support of bill was directed to the problems of providing and control of quality of commodities and services, and only one only division contained the norms intended for the protection of consumers. Thus, creation of this bill was a beginning step in appearance of legislation about the protection of rights of consumers. In connection with the productive necessity of that time the necessity of acceptance of certain norms of legislation, avouching for consumers a state supervision after execution and realization of their legal rights and freedoms, was first confessed [1, p. $8]$.

The second attempt of creation of the special legislation was creation for consumer legislation accepted on Mays, 221991 Namely Law in USSR on the main policy " protection of consumers"; However, in connection with disintegration of the USSR he so not entered into legal force. This Law contained the enormous amount of positions, not valid in a civil legislation, and also some ways of realization of all his norms. By a law existing on a that moment legal acts were not highly sought, however he forbade creation of department documents conflicting with interests of consumers straight. Thus, law of the USSR "On the protection of consumers" - became one of the first normative acts presenting to the consumers a right on the compensation of moral harm. Nevertheless some his positions carried declarative character the same $[2, \mathrm{p}$. 12].

All over the world a legislation about the protection of rights of consumers was formed in the last 50. Mainly all literary data to date reflected only inferiority of development of this legislation and were limited to the operating norms. Another brake in development of legislation about the protection of rights of consumers was a fact of legal force. Until now this legislation carried symbolic character and always lost on a hierarchy to the commercial laws. Thus, force of this mechanism on the protection of consumers remained limit, that generated a disbalance between consumers and enterprise segment on the whole. However this question behaves to the digit debatable on certain reasons that in accordance with some hypotheses limited legal interests of businessmen at entering of law into complete force [3, p. 15].

It became thus clear on practical experience, that the sharp division of segments became reason of unconfidence relations of consumers to the enterprise sector, that showed up in the certain level of legal nihilism among the certain layers of population, in accordance with that the representatives of enterprise sector became more confident in itself both in a legislation and in that legislation on their side. It allowed to some businessmen with impunity to carry out many productive machinations related to introduction to the turn of middling of subzero quality, here a consumer sector had some uncertainty in the forces on defending of the consumer rights [4, p. 11].

This factor resulted in weakening of marketing capabilities of segment of small enterprise, namely to the misbalance, caused by psychological fear of consumer before a businessman that brought after itself lowering over of level of competitiveness of businessmen, that in co-operating with the foreign segments of commercial subjects in international commercial legal relationships, as a rule, causes absorption of national markets foreign businessmen $[5$, p. 9$]$.

This problem in basis caused by it that national commodities and even level of salespeople in the state falls short of to the certain standards, at that quality of product and condition of serve of product to the consumers together with quality of service fall short of to the certain standard at that the level of trust of consumer to the salesman would remain stable. Thus, at undertaken studies some services were systematized, that allowed to define the level of relations of consumer to the different types of services and commodities [6, p. 2].

In respect of level of relations of consumer to the enterprise sector, a great deal in this problem follows from disparity of commodities to their documentary qualities, and similarly to properties described in the special informative folias - labels. In our time businessmen do not spare sufficient attention to these data, that is the marketing lack of education of businessman, that during small, but numerous transactions with consumers shows the low level of attention of businessmen to the consumer sector, that was maybe formed yet from times of universal deficit, at that a consumer had to be satisfied by that is $[7$, p. 21].

However times changed, the range of goods is presently high as never, here is a necessity to pursue a certain price policy flexible for every consumer on a separateness. On this basis, it is possible to suppose that the problem of cooperation lies not as commodities, and in ability of salesman, having mentality of times of deficit [8, p. 33].

At the market with expensive collection of information we find that imposition of limit on the costs of suppliers is diminished stimulus to become most informed about a market condition for consumers, so that in the total can grow the prices, conditioned by economic incuriosity of consumers. In the constrained model, where consumers have ability to refuse to get the produced marketing from businessmen, we find that this ability softens a price competition and can do all consumers losing materially, because absence of interest of consumers 
to the prices entails and absence of interest of consumers to properties of commodity, because opinion can appear for consumers, that all that they did not take a good value not very, because prices on all analogical commodities identically subzero $[9, \mathrm{p}$. $4]$.

However, the players of legal arena more deeply investigated the question of uninforming the enterprise sector of consumers, about what took away the conclusion, being base on example, group lawsuit, between the group of gamblers of drug addicts and government own gambling monopoly in Quebec (Sydney Morning Herald 11th. June 2001). This question touched unpresentation the organizers of games of reliable information concerning the rules of some events, that set at variance of world scales $[10$, p. 8$]$.

Thus, they gave an more deep example on modern events in the field of gaming, where the politics of realization of gaming before accepted and carried out in 1990th fell short of to the necessities of new millennium, that led to agitations of responsible playing subjects in the different regions of Australia, up to conflicts with a government. It proves that one little conflict in the field of protection of consumers can influence on all trade and economic politics of the state $[11$, p. 55].

Presently there is such problem as unstable market economy, where persons being in market relations salespeople mostly manipulate the choice of consumers, offering to them goods and services advantageous only for the profit. What be more, the factor of educating in accordance with that complicates the decision of this task, neither consumers nor competent in their defense public organs professionally trained in this sphere [12, p. $12]$.

\section{Conclusion.}

To sum up the case it is necessary to point out that consumer protection legislation is one of the most closely related cases for patient rights protection system, but to increase its effectiveness it must be developed during the period of education.

\section{References:}

1. Laurence MO, Fitzgerald J (2005) Fundamentals of Contract Law. Emond Montgomery Publication.

2. Köve V (2007) The Influence of PECL on Estonian Law of Obligations Act. Development of Estonian Contract and Company Law in the Context of the Harmonized EU Law. Tartu.

3. Steven Rogers, Tirk Krouli (2010) «Consumers Protection Legislation in Commercial Bloch War» Market Leader.

4. Joseph Bonnici, David P. Campbell, William B. Fredenberger, Kathryn H. Hunnicutt (2012) « Consumer Issues In Coupon Usage: An Exploratory Analysis» Illinois Business and Life Journal, Fall 2012.

5. Ronald E. Goldsmith and Charles F. Hofacker (1991) «Measuring Consumer Innovativeness», Journal of the Academy of Marketing Science 19. Summer 1991.

6. Roger D. Blackwell (1994) From the Edge of the World: Global Lessons for Personal and Professional Prosperity. Columbus: The Ohio State University Press.
7. Robert Blattberg, Gary Getz, and Jacqueiyn S. Thomas (2001) Customer Equity: Building and Managing Relationships as Valuable Assets. Boston: Harvard Business School Press.

8. Warren J Keegan (1993) global marketing managment 4 ed Prentce-Hall Internation Editions New York.

9. Twitchell, James B Adcult (1996) USA: The Triumph of Advertising in American Culture. New York: Columbia University Press.

10. Thomas MJ (1997) Consumer market research: does it have validity? Some postmodern thoughts. Marketing Intelligence \& Planning. Vol. 15. 1997. № 2.

11. Todd Ebitz (1993) «Italian Children May Be the Influencers», Market: Europe. January 1994; "Youth Marketing Isn't Dismissed as a Kid Stuff», Columbus Dispatch. March 4,1993.

12. Solomon MR (1992) Consumer Behavior: Buying, Having ang Being. 3-d ed. Prentice Hall, 704. 